\title{
Persekutuan Komanditer Sebagai Subjek Pemegang Hak Guna Bangunan Berdasarkan Surat Edaran Menteri ATR/BPN Nomor 2/SE-HT.02.01/VI/2019
}

\author{
Cokorda Istri Brami Putri Biya1 ${ }^{1}$ Dewa Gde Rudy ${ }^{2}$
}

${ }^{1}$ Fakultas Hukum Universitas Udayana,E-mail: cokistribrahmi@yahoo.co.id

2Fakultas Hukum Universitas Udayana,E-mail: gde_rudi@unud.ac.id

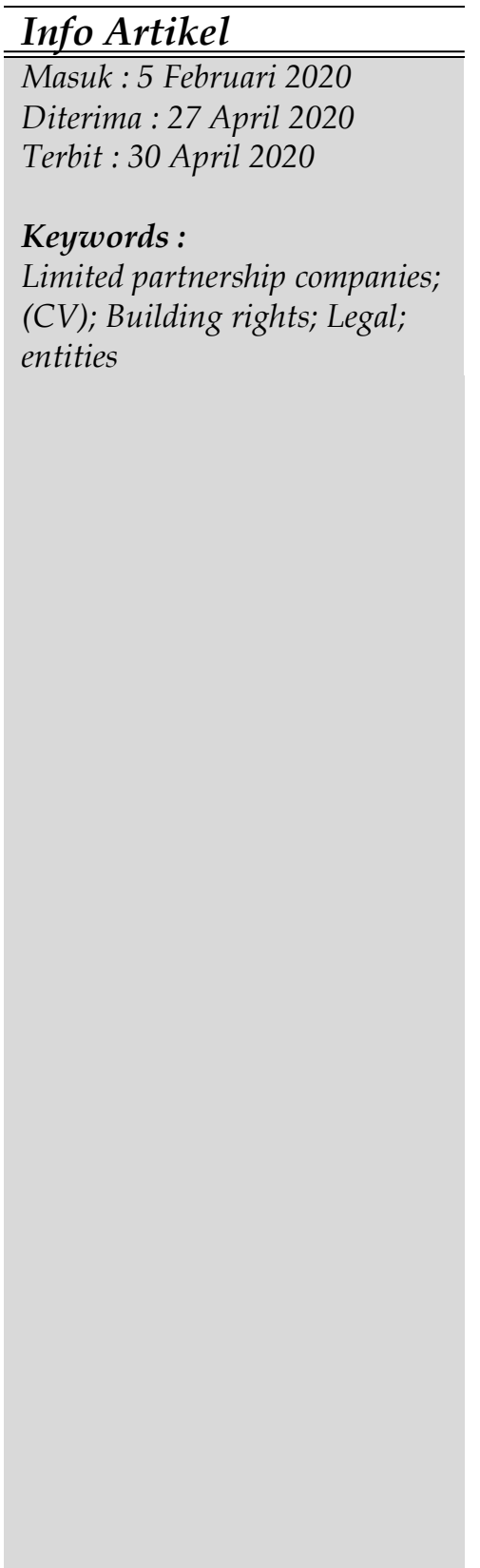

\begin{tabular}{l} 
Abstract \\
\hline This research is based on Circular Letter 2/SE- \\
HT.02.01/VI/2019, dated June 28, 2019 concerning the \\
Granting of Building Use Rights for the Military Alliance \\
(commanditaire vennootschap). This circular is a guideline for \\
implementing the granting of HGB to the temporary Limited \\
partnership companies (CV) when referring to Article 35 \\
paragraph (1) of the Agrarian Law that Building Rights can \\
only be owned by Indonesian Citizens and Legal Entities \\
established under Indonesian law and domiciled in Indonesia, as \\
also described in Article 19 Implementing Regulations, namely \\
Government Regulation Number 40 of 1996 concerning Land \\
Use Rights, Building Use Rights and Land Use Rights. Circular \\
Number 2/SE-HT.02.01/VI/2019, dated June 28, 2019 \\
concerning the granting of Building Rights for the Limited \\
partnership companies(CV), cause a conflicts of legal norms \\
between laws and regulations of one degree or another or \\
between laws and regulations in a hierarchical manner. \\
Furthermore is the arising of legal uncertainty from the \\
description above, the problems that can be raised in this study \\
are: What is the legal position of the Limited partnership \\
companies (CV) according to the legal provisions in Indonesia \\
and whether the Limited partnership companies (CV) can be \\
used as the subject of the Right to Use. This research uses the \\
Normative legal research method by using a type of approach in \\
the form of a statutory approach and an analytical conceptual \\
approach. Sources of legal materials used in this study include \\
primary, secondary and tertiary legal sources. The results of this \\
study indicate that the legal status of limited partnership (CV) \\
in Indonesian law is that Limited partnership companies(CV) is \\
not a legal entity but only as a business entity. This can be \\
assessed based on the characteristics of the legal entity that is the \\
separation of assets of the state-owned companies with the assets \\
of business entities, so that the state-owned companies are only \\
\hline
\end{tabular}


Kata kunci: Persekutuan Komanditer (CV);

Hak Guna Bangunan, Badan Hukum

\section{Corresponding Author:}

Penulis Pertama, E-mail: cokistribrahmi@yahoo.co.id

DOI :

10.24843/AC.2020.v05.i01.p02 responsible for the limited assets owned. Meanwhile, in $C V$, all active (complementary) and passive (limited partnership) companies may be held liable for losses suffered by $\mathrm{CV}$, as Article 21 of the Code of Business Lawthat said CV companies has jointly responsible and jointly responsible $(\mathrm{CV})$ cannot be the subject of Rights holder building

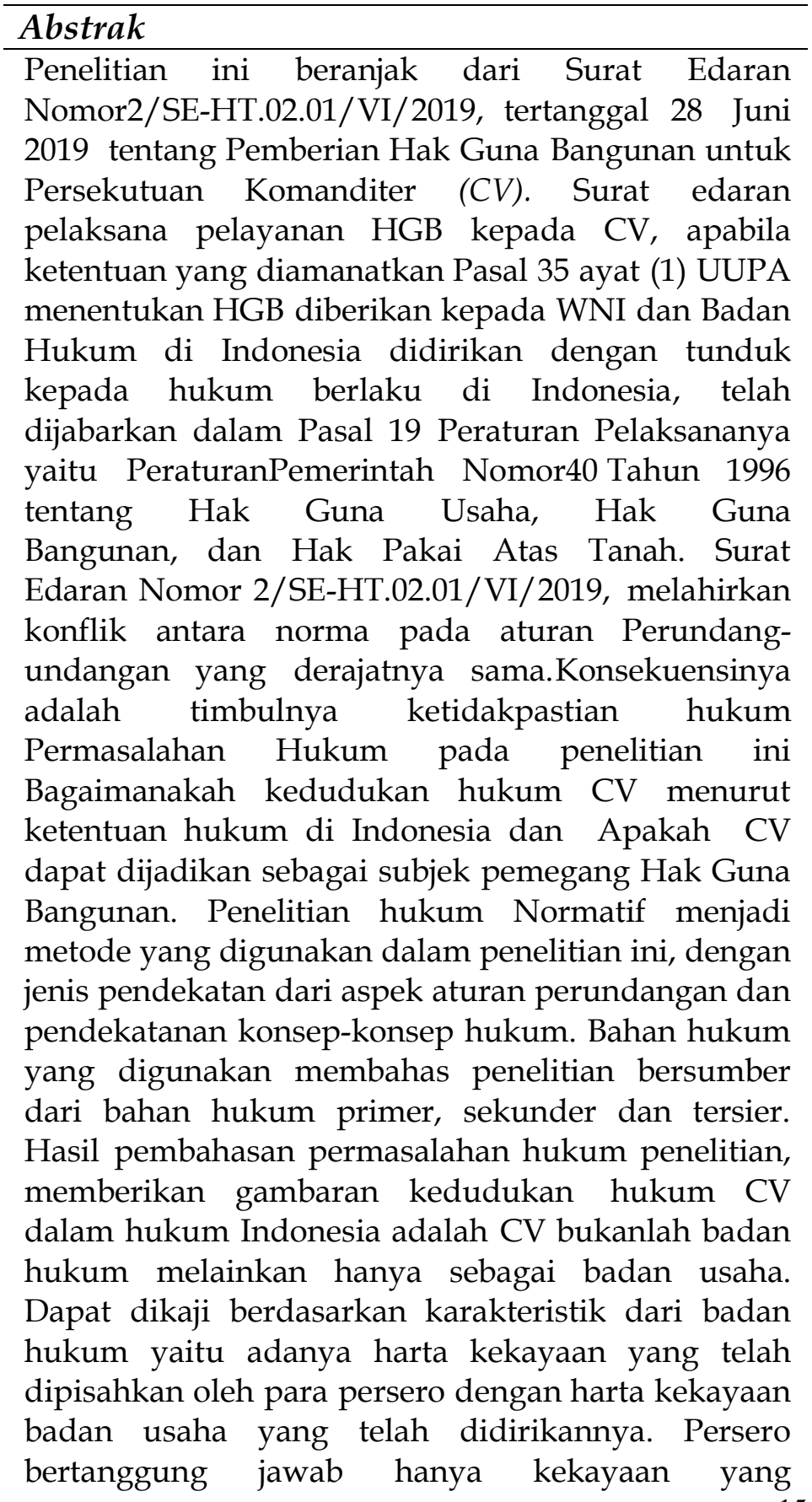




dimilikinya terbatas pada harta
Sementara, dimilikinya.
maupun persero pasif dapat dimintakan
pertanggungjawaban atas kerugiaan diderita oleh
$\mathrm{CV}$, sebagaimana Pasal 21 KUHD disebut
bertanggung jawab tanggung renteng dan CV tidak
dapat menjadi subjek pemegang HGB.

\section{Pendahuluan}

Merujuk kepada aturan dalam Pasal 33 ayat (3) UUD 1945, melahirkan suatu bentuk yakni hak menguasai suatu tanah oleh negara. Dalam ketentuan pasal tersebut menentukan bahwa "bumi dan air dan kekayaan alam yang terkandung di dalamnya dikuasai oleh negara dan dipergunakan sebesar-besarnya untuk kemakmuran rakyat" yang dapat diartikan Negara diberikan suatu kewenangan untuk mengelola sumberdaya alam termasuk tanah, sepenuhnya guna tercapainya cita-cita bangsa yaitu kemakmuran bagi seluruh rakyat Indonesia. Pada tataran pelaksanaan dari konsep tersebut, dirumuskan lebih terperinci pada ketentuan Pasal 2 ayat (1) UUPA yang pada prinsipnya Negara memiliki kekuasaan tertinggi untuk mengatur dan menyelenggarakan peruntukan dan penggunaan tanah, hanya saja yang menjadi poin penting dalam hal ini Negara menguasai tidak diartikan sebagai Negara bertindak selaku yang mempunyai tanah, namun hal nya Negara merupakan organisasi yang memiliki kekuasaan paling tinggi dari semua rakyat maupun bangsa dan bertindak sebagai badan dari penguasa.

Peruntukan dan pemanfaatan tanah penting untuk diatur oleh Negara mengingat tanah memiliki kaitan yang erat dengan tingkat kesejahteraan masyarakat hal ini tentu saja karena tanah memiliki nilai ekonomis, disamping itu tanah juga mempunyai nilai makna yang sangat mendasar dimana dengan memiliki hak atas tanah dalam jumlah banyak maka status sosial seseorang akan semakin tinggi. ${ }^{1}$ Sehubungan dengan hal tersebut maka pengaturan oleh Negara sangat dibutuhkan agar kepemilikan, peruntukan dan pemanfaatan tanah dapat merata sehingga diharapkan dapat meningkatkan pembangunan dan pertumbuhan ekonomi dalam negeri.

Berkaitan dengan mempercepat peningkatan pertumbuhan maupun pembangunan perekonomian dalam negeri, Negara melalui menteri menerbitkan aturan-aturan salahsatunya yakni Pemberian Hak Guna Bangunan untukk Persekutuan Komanditer (commanditaire vennootschap) selanjutnya disingkat CV. Adapun surat edaran ini merupakan petunjuk pelaksana pelayanan pemberian HGB kepada CV, dalam rangkaian investasi diseluruh wilayah Indonesia. Pada hakikatnya HGB merupakan hak diberikan untuk seluruh Warga Negara Indonesia dan Badan Hukum yang berkedudukan serta didirikan dengan hukum Indonesia guna mendirikan serta mempunyai bangunan-bangunan diatas tanah yang bukan milik

\footnotetext{
${ }^{1}$ Mahfiana layyin. (2016). Konsepsi Kepemilikan dan Pemanfaatan Hak atas Tanah Harta Bersama Antara Suami Istri, Buana Gender - Vol 1. p. 30
} 
sendiri untuk jangka waktu tertentu yakni 20 tahun atau 30 tahun sebagaimana disebutkan pada Pasal 35 ayat (1) Peraturan pokok-pokok Agraria. Lebih lanjut sehubungan dengan pengaturan HGB dijabarkan dalam Peraturan Pelaksananya yaitu Peraturan Pemerintah tentang HGB,HGU dan Hak Pakai Atas Tanah .

Dasar hukum CV diatur bersama-sama dengan Undang-undang mengenai Firma. Firma diatur dalam Pasall 16 sampai dengan Pasal 35 KUHD, diantara tiga banyaknya pasal itu tersedia yang mengatur CV yaitu Pasal 19, 20, dan

21 KUH Dagang. Dalam Pasal 19 KUHD menjabarkan CV sebagai perseroan yang terjadinya karena meminjamkan sejumlah uang, yang didirikan dari seseorang atau lebih dari satu orang persero yang bertanggungjawab secara berturut-turut dan satu orang persero atau lebih dari seorang bertindakk sebagai memberikan pinjaman orang. Pemberian pinjaman modal dalam hal ini dapat berwujud uang, misalnya barang atau tenaga (fisik atau pikiran) atau yang lainnya. Jika ditelusuri dalam KUHD, CV merupakan bentuk perusahaan atau dapat dikatakan sebagai perseroan dan bukanlah merupakan badan hukum, sebagaimana terdapat di buku pertama, title ketigaa, bagian kedua Pasal 16-35 KUH Dagang.

Dikaji dalam tataran normatif, surat edaran tentang Pemberian HGB untuk CV melahirkan konflik norma diantara peraturan perundangan satu dengan lain yang masih dalam satu tingkatan (sederajat) atau diantara perundangan satu dengan lain secara hierarki. Konsekuensi lebih lanjut adalah timbulnya ketidakpastian hukum yang berakibat timbulnya persoalan-persoalan hukum di kemudian hari, dan hal tersebut tentu saja bertentangan dengan salah satu tujuan hukum itu sendiri dimana hukum menjamin adanya kepastian hukum. Berdasarkan pemaparan di atas, penulis jadi tertarik mengkaji mengenai lebih mendalam "PERSEKUTUAN KOMANDITER SEBAGAI SUBJEK PEMEGANG HAK GUNA BANGUNAN BERDASARKAN SURAT EDARAN MENTERI ATR/BPN NOMOR 2/SE-HT.02.01/VI/2019".

\subsection{Rumusan Masalah,:}

1. Bagaimanakah kedudukan hukum Persekutuan Komanditer (CV) menurut ketentuan hukum di Indonesia?

2. Apakah Persekutuan Komanditer (CV) dapat dijadikan sebagai subjek pemegang Hak Guna Bangunan?

\subsection{Tujuan Penulisan}

Tujuan dari penulisan ini dapat di kelompokan menjadi berikut yaitu tujuan umum dan tujuan khusus, tujuan umum dapat dikatakan guna pengembangan ilmu hukum sebaliknya tujuan khusus sehubungan dengan mendalami rumusan masalah dari suatu penelitian. Dalam penelitian ini tujuan umum yang ingin dicapai adalah untuk memberikan kepastian hukum sehubungan dengan pemberian Hak Guna Bangunan bagi $\mathrm{CV}$ sementara itu tujuan khususnya yaitu untuk mengetahui bagaimana kedudukan $\mathrm{CV}$ di dalam Hukum Indonesia dan untuk mengetahui secara mendalam apakah CV dapat dijadikan sebagai Subjek pemegang Hak Guna Bangunan. 


\subsection{Orisinalitas Penelitian}

Dari penelusuran yang penulis lakukan terhadap seluruh penelitian terkait, sehubungan dengan CV sebagai subjek pemegang hak guna bangunan menurut Surat Edaran Menteri ATR/BPN, diketahui bahwa Penelitian tentang hal itu sampai detik ini belum terdapat yang sama. Namun akan tetapi dalam hal ini, penulis menemukan penelitian yang sejenis dan/atau terkait dengan penelitian ini yaitu penelitian dari Herawaty Nevy, Universitas Gajah Mada, tahun 2010, pada penelitian tersebut memfokuskan pada bagaimana akibat hukum CV yang telah memperoleh HGB dan yang menjadi dasar kajiannya adalah UUPA sementara itu pada penelitian ini akan menguraikan secara lebih menyeluruh dan baik UUPA, Peraturan Pemerintah terkait dan tentunya surat edaran sebagaimana dimaksud tersebut, selain itu yang menjadi dasar pembeda utama adalah pada penelitian sebelumya dilakukan pada tahun 2010 sebelum diterbitkannya surat edaran tersebut, dan pada penelitian ini dilakukan dengan memfokuskan pada surat edaran yang baru diterbitkan tersebut sehingga penelitian ini sangatlah baru dan belum pernah ada.

\section{Metode Penelitian}

\subsection{Jenis Penelitian}

Penelitian hukum Normatif menjadi pilihan metode digunakan melangsungkan penelitian ini. Penelitian hukum normatif sendiri merupakan suatu penelitian hukum kepustakaan. ${ }^{2}$ Penelitian hukum kepustakaan dapat dilakukan pada peraturan- peraturan yang tertulis dan pada bahan-bahan hukum yang lain. Penelitian hukum normatif dipilih dalam penulisan karya ilmiah ini, karena beranjak dari konflik norma yang terjadi karena diterbitkannya Surat Edaran Nomor 2/SEHT.02.01/VI/2019, tertanggal 28 Juni 2019 tentang Pemberian Hak Guna Bangunan untuk Persekutuan Komanditer (commanditaire vennootschap). Pertentangan peraturan perundang- undangan yang timbul yaitu antara aturan yang mengatur mengenai subjek hukum yang dapat memiliki HGB, dengan ketentuan yang mengatur mengenai $\mathrm{CV}$ sebagai perusahaan/perseroan yang bukan berbadan hukum.

\subsection{Jenis Pendekatan}

Jenis pendekatan digunakan untuk memperoleh informasi mendalam sehubungan dengan isu hukum yang sedang dicari jawabannya. Pada penelitian ini menggunakan jenis pendekatan dari aspek aturan perundangan (statute approach) dan pendekatanan konsep-konsep hukum (analitical conceptual approach). Pendekatan perundangan digunakan khususnya pada perundangan yang terkait dengan $\mathrm{CV}$ dan pengaturan HGB sementara itu pendekatan konsep dilakukan khususnya terhadap konsep suatu badan hukum dan konsep pemberian HGB.

\subsection{Sumber Bahan Hukum}

Mengkaji mengulas dan membahas permasalahan hukum yang ada, banyak sumber bahan hukum yang dipakai yakni, bahan hukum primer bersumber dari

\footnotetext{
${ }^{2}$ R. Soejono Soekanto. 2013. Penelitian Hukum Normatif (Sutau Tinjauan Singkat). Jakarta : Raja Grafindo Persada. p. 23..
} 
ketentuan ketentuan peraturan perundang-undangan, bahan hukum sekunder berasal dari beberapa buku, jurnal tentang hukum, skripsii, disertasi, tesis hukum, dan juga gagasan atau pandangan dari para ahli hukum, dalam hal lain bahan hukum tertier yang merupakan penunjang serta diharapkan dapat membantu memberi petunjuk dan kejelasan terhadap bahan hukum primer dan bahan hukum sekunder, yang dapat bersumber dari kamus hukum dan ensiklopedia hukum, yang relevan dengan objek kajian penelitian hukum ini.

\subsection{Teknik Pengumpulanbahan hukum}

Teknik studikepustakaan maupun sistem kartu kedua system ini disebut juga (Study Document / card system) menjadi pilihan penulis dalam pengumpulan bahan hokum. Dalam penelitian ini, banyak bahan hukum yang digunakan yang dianggap relevan oleh penulis melalui tulisan ini ditulis, khususnya terhadap banyak hal dikiranya sangat penting, dengandemikian bisa lebih gampang untuk diresapi.

\subsection{Teknik Analisis Bahan Hukum}

Melaksanakan penelitian ini penulis mengawali dengan menyiapkan semua bahan hukum yang ada kemudian terhadapnya dilakukan pemilahan secara sistematis sehingga dapat dengan mudah untuk dianalisa. Analisa bahan hukum yang penulis lakukan demi mengetahui dan memahami hingga keakarnya terhadap permasalahan hukum yang ada. Dalam hal ini penulis menggunakan teknik deskripsi yaitu teknik yang menggambarkan secara menyeluruh terhadap aturan perundangan yang ada, kemudian dihubungkan dengan permasalahan hukum yang sedang di bahas. Selain itu penulis juga menggunakan teknik evaluasi, dimana penulis mengevaluasi bahanbahan hukum penulisan ini guna memberikan suatu penilaian terhadap norma dan banyak keputusan yang ada.

\section{Hasil Dan Pembahasan}

3.1. Kedudukan Hukum Persekutuan Komanditer (CV) Menurut Ketentuan Hukum di Indonesia

Sumber hukum perusahaan di Indonesia diatur dalam Kitab Undang-Undang Hukum Dagang (KUHD), Kitab Undang-Undang Hukum Perdata (KUHPer), Perundangan RI, Kebiasaan dan Yurisprudensi. Akan tetapi yang menjadi sumber utamanya tetaplah KUHD. Menurut Abdulkadir Muhammad, perusahaan dapat diklasifikasikan menjadi beberapa klasifikasi antara lain, dipantau dari nominal pemilik dari perusahaan, yaitu perseorangan dan persekutuan. Sementara itu jika dipilah berdasarkan kepemilikan, ada perusahaan swasta dan perusahaan negara, dan jika dipilah dari bentuk hukumnya, maka terdapat perusahaan yang berbadan hukum dan yang bukan berbadan hukum

Kedudukan hukum Persekutuan komanditer atau yang biasa disingkat CV (Commanditaire Vennootschap) dalam hal ini akan difokuskan pada klasifikasi CV berdasarkan bentuk hukumnya. Pengaturan CV terletak diantara Pasal-pasal yang mengatur mengenai firma yaitu dalam Pasal 16-35 KUHD, hal demikian karena CV adalah persekutuan firma dengan bentuk khusus yaitu persekutuan firma yang 
mempunyai satu atau lebih sekutu komanditer. CV sendiri pada prakteknya dapat didirikan oleh orang perorangan maupun perseroan (badan hukum).

CV menurut Pasal 19 KUHD yaitu perseroan yang terbentuk dengan cara meminjamkan uang, yang didirikan oleh seorang atau beberapa orang persero yang bertanggung jawab secara tanggung renteng dan satu orang persero atau lebih yang bertindak sebagai pemberi pinjaman uang. Dengan demikian dapat dikatakan jika pasal tersebut terdapat dua organ penting didalam suatu CV, Pertama, persero aktif adalah persero yang bertanggung jawab penuh secara tanggung renteng dan persero aktif merupakan persero yang mengendalikan roda suatu $\mathrm{CV}$, atau persero komplementer. Kedua adalah persero yang memberikan suatu pinjaman uang (persero pasif, persero komanditer). Secara sederhana dapat diartikan persero aktif merupakan pihak yang mempunyai tanggung jawab penuh dalam mengelola perusahaan dengan jabatan sebagai direktur sebaliknya persero pasif merupakan orang yang mempunyai tanggung jawab hanya sebatas modal yang ditempatkan atau dapat dikatakan hanya sebagai pemegang saham.

Jika mengutip pandangan H.M.N. Purwosujipto, pada hakekatnya tidak ada bentuk perusahaan perseorangan yang resmi, maka dari itu dalam KUHD maupun peraturan perundang-undangan lainya tidak dapat dijumpai adanya pengaturaan yang bersifat secara khusus yang mengatur sehubungan dengan perusahaan perseorangan sebagaimana halnya bentuk usaha lainnya seperti Perseroan Terbatas (PT), persekutuan komanditer (CV), maupun koperasi. Sementara itu dalam sektor bisnis, masyarakat telah mengenal dan menerima perusahaan perseorangan yang berbentuk usaha dagang (UD). Bentuk perusahaan tersebut dinegara-negara maju disebut dengan sole traders atau sole proprietorships. Tipe Perusahaan yang demikian merupakan tipe perusahaan yang sangat sederhana di mana seorang pengusaha memiliki sendiri seluruh aset perusahaannya sehingga bertanggung jawab sendiri juga atas seluruh utang perusahaan. Suatu perusahaan juga dapat bertanggung jawab sendiri sebatas modal yang dimilikinya tanpa menjadi tanggung jawab para pendirinya, dalam hal ini maka suatu perusahaan tersebut haruslah berbadan hukum.

Badan hukum merupakan salah satu subjek hukum, subjek hukum dalam hukum perdata memiliki peranan yang penting mengingat berkaitan dengan kewenangan. Subjek hukum sendiri merupakan pendukung hak dan kewajiban dalam hal ini adalah manusia dan badan hukum. Dengan demikian dapat diartikan bahwa subjek hukum mempunyai hak dan kewajiban. Menurut hukum di Indonesia selain manusia, badan-badan dipandang sebagai subjek hukum yang dapat menjalankan kewajiban serta memiliki hak selayaknya manusia, dimana hal tersebut tercermin dari badan-badan yang dapat memiliki kekayaan tersendiri serta dapat bertindak di dalam maupun di luar pengadilan. Oleh karena badan hukum dipandang memiliki hak dan kewajiban maka badan hukum dapat mengadakan hubungan hukum baik antara badan hukum yang satu dengan lainnya maupun antara badan hokum dengan perseorangan (manusia).

Menurut E Utrech badan hukum yang memiliki kewenangan menjadi pendukung hak yang tidak berjiwa atau lebih tepatnya manusia. Sementara itu menurut ridwan untuk dapat dikatakan sebagai badan hukum maka harus memenuhi unsur adanya kekayaan yang terpisah, mempunyai tujuan tertentu dan mempunyai 
kepentingan sendiri. Dewasa ini seiring dengan perkembangan hukum dimasyarakat suatu badan dapat dikatakan sebagai badan hukum haruslah memenuhi lima kriteria penting yaitu :

1. Mempunyai kekayaan yang terpisah

2. Memiliki tujuan ideal

3. Mepunyai kepentingan sendiri dalam hukum

4. Kepengurusannya bersifat teratur menurut peraturan perundangundangan

5. Terdaftar sebagai badan hukum

Dari apa yang telah diuraikan tersebut maka adapun hal yang utama suatu badan dapat dikatakan sebagai badan hukum (recht person) adalah adanya kekayaan yang terpisah, hal ini sesuai dengan teori kekayaan yang bertujuan dimana menurut teori ini suatu badan hukum kekayaannya dipandang terpisah atau berbeda dari yang memegangnya, maka dalam hal ini tidak penting siapa badan hukum tersebut akan tetapi kekayaan yang terpisah tersebut digunakan guna mencapai tujuan tertentu sehingga menurut teori ini tidak dibedakan baik manusia atau bukan yang paling penting adalah tujuan dari kekayaan tersebut dengan demikian maka badan hukum memiliki hak dan kewajiban selayaknya manusia sehingga dapat menjalankan hak dan kewajibannya pada pihak ke tiga. Sesuai dengan apa yang diuraikan diatas serta teori yang telah dijabarkan, karakteristik dari badan hukum adalah adanya pemisahan harta kekayaan para persero dengan kekayaan badan usaha, sehingga para persero hanya bertanggung jawab sebatas harta yang dimilikinya

Pada tanggal 1 Agustus 2018, pemerintah RI telah mengundangkan Peraturan Menteri Hukum dan Hak Asasi Manusia No. 17 tahun 2018 tentang Pendaftaran CV, Firma dan Persekutuan Perdata (Permenkumham No. 17/2018), yang pada Pasal 3 ayat (2)-nya menentukann bahwa CV, Firma, dan Persekutuan Perdata diajukan melalui Sistem Administrasi Badan Usaha (SABU). Di SABU diakui kedudukannya CV sebagai Badan Usaha dan bukan Badan Hukum, begitu pula pada Pasal 3 ayat (1) bahwa pendaftaran CV diajukan kepada menteri, yang digaris bawahi adalah kata pendaftaran, berbeda dengan PT bahwa mendapatkan pengesahan dari Menteri. selain apa yang diuraikan di atas dapat dilihat dari hukum kepailitan yang berlaku di Indonesia yang menyebutkan bahwa CV bukanlah suatu badan hukum sehingga tidak dapat dinyatakan pailit, kepailitan dalam CV memiliki arti bahwa pailit dari para sekutunya karena pada dasarnya utang yang tidak dibayarkan tersebut merupakan utang dari para persero CVnya.

Sehingga dari penjabaran diatas maka dapat disimpulkan bahwa kedudukan CV bukanlah merupakan badan hukum melainkan hanya sebagai badan usaha.Sebagaimana ketentuan dalam KUHD yang menegaskan seluruh persero aktif (pengurus)maupun persero pasif dapat dimintakan pertanggungjawaban atas kerugiaan yang diderita oleh CV, yang dalam Pasal 21 KUHD disebut bertanggung jawab secara tanggung renteng. Selain itu, adanya kewajiban CV untuk didaftarkan ke SABU, tidak juga menjadikan CV sebagai Badan Hukum dan tetap merupakan Badan Usaha yang mempunyai tanggung jawab sampai dengan harta pribadi. 
3.2. Persekutuan Komanditer (CV) sebagai subjek pemegang Hak Guna Bangunan.

Hak Guna Bangunan (HGB) merupakan salah satu hak atas tanah yang diatur dalam Peraturan Dasar Pokok-Pokok Agraria (UUPA) pada Pasal 35 ayat (1) yang menentukan "Hak Guna Bangunan adalah hak untuk mendirikan dan mempunyai bangunan-bangunan atas tanah yang bukan miliknya sendiri, dengan jangka waktu paling lama 30 tahun". Dalam ketentuan Pasal 35 ayat (2) ditentukan juga bahwa atas permintaan pemegang hak, jangka waktu tersebut dalam ayat (1) dapat diperpanjang 20 tahun lagi.

Lebih lanjut dalam Pasal 36 UUPA, menentukan yang dapat memperoleh hak sebagai subjek HGB adalah Warga Negara Indonesia dan Badan Hukum yang didirikan menurut hukum Indonesia dan berkedudukan di Indonesia. Hal ini merupakan perwujudan dari prinsip nasionalitas hak-hak atas tanah di Indonesia, artinya dalam hal pemilikan tanah, WNI sebagai pihak yang diberikan tempat untuk mendapatkan tempat sepenuhnya atas tanah di Indonesia. ${ }^{3}$ Selaras dengan UUPA, peraturan pelaksana dari UUPA pada Pasal 16 mengenai hak-hak atas tanah yaitu Peraturan Pemerintah Nomor 40 Tahun 1996 tentang Hak Guna Usaha, Hak Guna Bangunan dan Hak Pakai atas tanah pada Pasal 19 juga menentukan bahwa subyek dari HGB adalah Warga Negara Indonesia dan Badan Hukum yang didirikan menurut hukum Indonesia dan berkedudukan di Indonesia. Sebagaimana tersebut menunjukan bahwa CV tidak termasuk dalam kategori subjek pemegang HGB, karena merujuk pada pembahasan sebelumnya bahwa kedudukan $\mathrm{CV}$ hanya sebagai badan usaha dan bukanlah sebagai badan hukum.

Keberadaan Surat Keputusan berupa Surat Edaran Menteri ATR/BPN nomor 2/SE-HT.02.01/VI/2019 tanggal 28 Juni 2019 yang tentang pemberian HGB untuk CV menimbukan pertentangan atau konflik antara norma yang satu dengan yang lain. Berdasarkan teori kepastian hukum, menurut Radbruch yang menyebutkan bahwa hukum harus memenuhi berbagai karya yaitu keadilan, kegunaan dan kepastian hukum yang disebut sebagai nilai-nilai dasar dari hukum. Kepastian hukum sebagai nilai-nilai dasar hukum dapat juga dikatakan kepastian hukum sebagai salah satu tujuan hukum dan kepastian hukum dari hukum itu sendiri berarti dalam suatu peraturan perundang-undangan dituntut untuk tidak menimbulkkan ketentuanketentuan yang dapat ditafsirkan berlainan atau multi tafsir. Adapun maksud dan tujuan dari Surat Edaran ini pada dasarnya sebagai petunjuk pelaksanaan untuk pemberian Hak Guna Bangunan kepada CV. Surat Edaran dari Menteri ATR/BPN ini "membuka ruang" dan memberi "aturan teknis pelaksanaan" untuk melakukan "pencatatan kepemilikan hak atas tanah dengan cara nomenie", hal demikian karena nama yang tercatat dalam buku tanah di kantor pertanahan setempat dan atas Sertifikat HGB bukan pemilik hak atas tanah (HGB) yang sebenarnya. HGB yang diberikan kepada $\mathrm{CV}$ adalah atas nama persero aktif dan persero pasif (seluruh anggota) dengan dicantumkan jumlah-jumlah modal dari para persero atau salah satu anggota berdasarkan persetujuan seluruh persero. Dalam hal ini menunjukan bahwa pemberian HGB adalah kepada orang perorangan dalam $\mathrm{CV}$ bukan untuk $\mathrm{CV}$.

\footnotetext{
${ }^{3}$ Ni Made Irpiana Prahandari. (2015). Penguasaan Hak Milik Atas Tanah Milik Warga Negara
} 
Merujuk pada ketidakpastian hukum tersebut diatas, maka berdasarkan teori hierarki norma atau yang dikenal dengan sebutan penjejangan norma adalah teori yang dikemukakan oleh Hans Kelsen dimana disebutkan jika suatu sistem hukum adalah sistem selayaknya pada anak tangga dengan kaidah atau aturan yang memiliki tingkatan atau penjenjangan. Pada suatu puncak susunan suatu norma, norma atau kaidah yang lebih tinggi akan selalu menjadi sumber serta dasar bagi norma yang ada dibawahnya atau pada tingkatan yang lebih rendah sebaliknya yang ada pada tingkatan lebih rendah senantiasa akan selalu bersumber merujuk kepada pada norma yang lebih tinggi. Tingkatan-tingkatan tersebut terus berlanjut hingga pada norma yang paling tinggi dan bersifat mendasar (grundnorm). Semua hukum bersumber dari grundnorm (norma dasar), dan seluruh tata hukum positif harus berpedoman secara hierarki pada grundnorm.

Adapun rujukan terhadap teori hierarki norma pada tatanan norma hukum di Indonesia yaitu pada ketentuan Undang-Undang No. 12 tahun 2011 tentang pembentukan peraturan perundang-undangan. Pada pasal 7 ayat (1) disebutkan bahwa, Jenis dan hierarki Peraturan Perundang-undangan terdiri atas: UUD NKRI 1945, Ketetapan MPR, Undang-Undang/Peraturan Pemerintah Pengganti UndangUndang, PeraturanPemerintah, PeraturanPresiden, PeraturanDaerah Provinsi dan PeraturanDaerah Kabupaten/Kota. Sebagai konsekuensinya dari adanya penjenjangan tersebut dalamsuatuu pembentukan peraturanperundang-undangan yang tingkatannya lebih rendah haruslah bersumber merujuk pada ketentuan aturan yang di atasnya atau lebihtinggi dari hal tersebut terus berkelanjutan sehingga pada akhirnya yang lebih tinggi bersumber pada yang tertinggi tingkatannya sehingga dengan demikian suatu peraturanperundang-undangann yang tingkatannya berada dibawah senantiasa harus merujuk pada yang lebih tinggi sehingga nantinya tidak membuat suatu konflik dengan peraturanperundang-undangan yang lebihtinggi tersebut.

Undang-Undang tentang pembentukan peraturan perundang-undangan, Surat Edaran Menteri ATR/BPN tidak dapat diklasifikasikan dalam peraturan perundang-undangan, karena pada dasarnya Surat Edaran bukan merupakan peraturan perundang-undangan (regeling), juga bukan Keputusan Tata Usaha Negara (beschiking), tetapi hanya sebagai peraturan kebijakan. Namun demikian, sebuah peraturan kebijakan tetap harus merujuk dan bersumber pada peraturan perundang-undangan yang di atasnya atau lebih tinggi, sehingga tidak menimbulkan konflik norma yang dapat menimbulkan ketidakpastian hukum.

Permasalahan-permasalahan lain terkait dengan ketidakpastian hukum pemberian HGB kepada CV yaitu apabila salah satu persero atau sekutu meninggal dunia ataupun salah satu sekutu ingin keluar dari CV atau juga jika terjadi pergantian sekutu bagaimana dengan nama-nama sekutu tersebut yang sudah tercantum di dalam sertifikat, sebagaimana dalam sertifikat yang dicantukan adalah nama anggota persero. Maka akan timbul permasalahan lain, ada baiknya suatu aturan baik aturan yang berada diatasnya maupun peraturan pelaksananya haruslah tidak menimbulkan konflik norma sehingga dapat memberikan kepastian baik pada aturannya sendiri maupun pada masyarakat. Kepastian hukum tidak bisa dielakkan lagi di tengah keperluan banyak warga akan tanah maupun ekonomi dan bisnis yang semakin meningkat. 


\section{Kesimpulan}

1. Kedudukan hukum perseroan komanditer (CV) dalam hukum Indonesia adalah $\mathrm{CV}$ bukanlah merupakan badan hukum melainkan hanya sebagai badan usaha. Hal ini dapat dikaji berdasarkan karakteristik dari badan hukum yaitu adanya pemisahan harta kekayaan para persero dengan kekayaan badan usaha, sehingga para persero hanya bertanggung jawab sebatas harta yang dimilikinya. Sementara itu, didalam CV seluruh persero aktif (komplementer) maupun persero pasif (komanditer) dapat dimintakan pertanggungjawaban atas kerugiaan yang diderita oleh CV, sebagaimanna Pasal 21 KUHD disebut bertanggung jawab secara tanggung renteng.

2. Persekutuan Komanditer (CV) tidak dapat menjadi subjek pemegang Hak Guna Bangunan, karena berdasarkan UUPA pada Pasal 35 ayat (1) dan PP No. 40 Tahun 1996 tentang Hak Guna Usaha, Hak Guna Bangunan, dan Hak Pakai atas Tanah, yang menjadi subjek pemegang HGB adalah Warga Negara Indonesia dan Badan Hukum yang didirikan menurut hukum di Indonesia dan berkedudukan di Indonesia. Sementara itu CV berdasarkan KUHD bukan merupakan Badan Hukum tetapi hanya sebagai badan usaha.

\section{Daftar Pustaka}

\section{Buku}

Arrasjid, Chainur. (2008) Dasar-dasar Ilmu Hukum. Jakarta : Sinar Grafika. Ed. 1. Cet. 5.

Asikin, H. Zainal dan L. Wira Pria Suhartana. (2016). Pengantar Hukum Perusahaan. Depok : Prenadamedia Group. Edisi Pertama. Cet. Kedua.

Imaniyati, Neni Sri. (2009). Hukum Bisnis Telaah Tentang Pelaku dan Kegiatan Ekonomi. Yogyakarta : Graha Ilmu.

Ishaq. (2016). Dasar-dasar Ilmu Hukum. Jakarta : Sinar Grafika. Ed. Revisi. Cet. 1.

Kelsen, Hans. (2009). General Theory of Law and State, Translated by Anders Wedberg, Harvard University Printing Office Cambridge, Massachusetts, USA.

Pasek Diantha, I Made. (2016). Metodologi Penelitian Hukum Normatif Dalam Justifikasi Teori Hukum. Jakarta : Kencana. Cet. 1.

Saliman, Abdul R., (2005). Hukum Bisnis Untuk Perusahaan : Teori dan Contoh Kasus, Jakarta : Kencana. Edisi Keempat, Cet. Ke-8.

Soekanto, R. Soerjono dan Sri Mamudji. (2004). Penelitian Hukum Normatif. Jakarta : PT. Raja Grafindo Persada. Cet. VIII. 
Tanya, Bernard L., Yoan N. Simanjuntak dan Markus Hage. (2013). Teori Hukum (Strategi Tertib Manusia Lintas Ruang dan Generasi). Jakarta : Genta Publishing.

Triwulan, Tutik. (2008). Hukum Perdata Dalam Sistem Hukum Nasional. Jakarta : Prenada Media Group.

\section{Jurnal}

Agus Wahyu Dharmawan Redhana. (2015). Pembuatan Perjanjian Kawin oleh Pasangan

Suami Istri yang Beragama Hindu Yang Perkawinannya Belum Dicatatkan. Kertha

Pertiwi. Volume 11.

Layyin, Mahfiana. Konsepsi Kepemilikan dan Pemanfaatan Hak atas Tanah Harta Bersama antara Suami Istri. Buana Gender - Vol 1. Nomor : 1 Januari-Juni 2016.

Novita Diana Safitri. Pertanggungjawaban Sekutu Dalam Persekutuan Komanditer Yang Mengalami Kepailitan. Kertha Semaya-Vol. 06, Nomor : 2. 13 Maret 2018.

\section{Internet}

Notary Magazine, https://notarymagazine.com/kajian-dan-analisis-se-menteri-atrnomor-2-tahun-2019 tentang-pemberian-hak-guna-bangunan-untuk-persekutuankomanditer/ diakses pada tanggal 14 September 2019 